\title{
The Saudi Vision 2030: Reproduction of Women's Empowerment in the Saudi Press: A Corpus-based Critical Discourse Analysis
}

\author{
Naeem Afzal, ${ }^{1 *}$ Abdulfattah Omar $^{2}$ \\ ${ }^{1}$ Department of English, College of Science \& Humanities, Prince Sattam Bin Abdulaziz \\ University, Al-Kharj 11942, Saudi Arabia, ${ }^{2}$ Department of English, Faculty of Arts, Port Said \\ University, Port Said, Egypt \\ *) Corresponding Author \\ Email:n.awan@psau.edu.sa \\ DOI: 10.18326/rgt.v14i1.121-138 \\ Submission Track: \\ Received: 02-04-2021 \\ Final Revision: 26-05-2021 \\ Available Online: 08-06-2021 \\ Copyright @ 2021 Authors
}

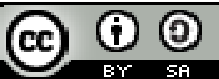

This work is licensed under a Creative Commons Attribution-ShareAlike 4.0 International License.

\begin{abstract}
The Kingdom of Saudi Arabia has witnessed unprecedented reforms within the framework of the Saudi Vision 2030. However, despite prolific news reports related to economic, social, and political reforms associated with the Saudi Vision 2030, there is a general lack of studies on the ideological constructions of these reforms in the Saudi press. As thus, this study seeks to explore the news representation and ideological construction of the vision 2030 reforms in the Saudi press. It focuses on the reproduction of women's empowerment in the Saudi press. For this purpose, a corpus of 1578 newspaper articles, reports, stories, and editorials published in Arab News and Saudi Gazette is designed. Analysis of the data is carried out through corpusbased critical discourse analysis (CDA) quantitatively and qualitatively through concordance, frequency, collocates, and dispersion. Results indicated that the Saudi press, under its ideological orientation, reproduced the vision 2030 as a matter of public interest. Both newspapers exhibited a great inclination towards endorsing women's empowerment as stipulated in the vision. The Saudi Vision's representation of women's empowerment was reflected and reproduced in many ways in newspapers' articles, reports, stories, and editorials. This study was limited to the newspaper content released after the emergence of the Saudi Vision in 2016. Further research is recommended on the influence of the Saudi press on the representation of women's rights discourse in the Saudi Vision 2030; it may also include the public opinion about such transformational reforms.
\end{abstract}

Keywords: corpus-based CDA, discourse reproduction, newspaper representations, Saudi Vision 2030, women's empowerment 


\section{INTRODUCTION}

The Kingdom of Saudi Arabia has witnessed rapid social, cultural, economic, and political changes within the framework of a vision (referred to as the Saudi Vision 2030) as an ambitious program of improvement for Saudi Arabia led by Crown Prince Mohammed bin Salman (Alsaaidi, 2020; Badran, Baydoun, \& Hillman, 2019; Burton, 2016; Makhlouf, 2021). On September 26, 2017, for instance, Saudi Arabia's King Salman bin Abdul Aziz issued an order to allow women to have a driver's license, following Shari'a rules, for the first time in Saudi history. This move comes within a series of political reforms run by the government, which reflects its commitment to human rights in the Kingdom. The vision is said to change Saudi Arabia into a strong country with a vibrant society, a thriving economy, and an ambitious nation.

The strategy of the vision has three important pillars including Saudi Arabia's state as the heart of the Arab and Muslim world, the determination to be a global investment, and making Saudi Arabia a trade gateway to the world. The Vision has focused on various fields including social and cultural fields, religious fields, economic, and political fields. It has many goals such as making Saudi Arabia an investment power, staying connected to Europe, Asia, and Africa, providing equal opportunities for all Saudi citizens, increasing the number of Umrah visitors, paying attention to education, health care, encouraging the private sector and giving women new roles, for instance, the right to drive. As a broader national modernization project, the vision 2030 concerning cultural and social development allows Saudi citizens to enjoy a good quality of life and makes them trained for the job market. It leads to the appearance of industries, gives the chance for women to be employed, pays attention to human capital and talent promotion, gives interests to the public investment fund, increases the private sector's contribution, and attracts talents. The Vision also develops the political field of Saudi Arabia as it initiates a program of reconstructing government levels and allows women's participation and contribution to various fields of developments (Alomair, 2018; Alsuraihi, 2019; Koch \& Tabatabai, 2020).

The Vision 2030 received extraordinary attention from the print, electronic and social media in the country. However, very little has been done on the representation of human rights and women's empowerment in the Saudi press. 
In light of this argument, this study seeks to explore the role of the media in the promotion, reproduction, and representation of human rights in the light of vision 2030 employing a corpus-based critical discourse analysis approach. CDA is useful to probe the relations between discourse, society, and culture by revealing the implicit agenda of media discourses (van Dijk, 1995a). It refers to the investigation of social problems by placing emphasis on the manipulation of language as its vital features (Van Dijk, 2006; Wodak 2001). In addition, CDA unveils the relation between events, texts, and discursive practices in alignment with socio-political and socio-cultural aspects (Fairclough, 2013; Kress, 1990). The two key features of discourse, namely, production and reception and important entities of CDA that exhibit the way dominance is expressed in the production of a text via the employment of rhetorical, persuasive, lexical, and syntactic choices, semantic structures, argumentations, and what impressions are carved in the minds of readers (van Dijk, 1993).

Since its publication, the Vision 2030 has attracted several scholars who investigated the document from various angles. Mitchell and Alfuraih (2018) analyzed the Saudi Arabian National Transformation Program 2020 and Saudi Vision 2030. An investigation was made to identify the associated curriculum orientations within the two documents to determine what the Kingdom of Saudi Arabia sought to achieve and how it envisioned accomplishing these aspirations through educational developments. The study revealed that the imperative of the two visionary documents was to establish a knowledge-based economy whereas education was envisaged as a means to foster such imperatives.

Dahim (2018) investigated the impact of value-added tax and increase in fuel prices, implemented by Saudi Vision 2030, on road traffic accidents, injuries, and fatalities. The study concluded that an increase in gasoline prices contributed to short-term and intermediate-term decreases in on-road traffic accidents, injuries, and fatalities.

Altoaimy (2018) explored the use of Twitter in the debate on women's right to drive in the Kingdom of Saudi Arabia. The study investigated how gender roles and the relationship between the genders were navigated in such debates. It followed a corpus-assisted discourse studies approach to analyzed arguments given by Twitter users about the KSA's ban on women drivers. 
Alharbi (2018) analyzed the Saudi healthcare system's readiness to change in the context of the Vision 2030. The study concluded that high organizational readiness for change, availability of resources, and alignment of situational factors could cause members of an organization to take changeoriented initiatives that may facilitate effective implementation of the Saudi healthcare transformational plan.

Bah (2018) investigated the feasibility of the gain in life expectancy outlined in the Vision 2030 document. The study concluded that the vision is an important milestone meant to improve the population's health and social wellbeing. It claimed that fundamental drivers of life expectancy must be addressed to achieve certain gains in life expectancy.

Daghestani, Almunajem, Alabdulkarim, Alnuaim, and Albassam (2018) explored the effect of the 2030 vision on the performance of the Saudi stock market; Changes in investors' behavior were investigated before and after the implementation of the vision. The study revealed that investors became more cautious in planning for future income and expenses and increased their efforts.

Under the perception that media play an instrumental role in creating public awareness and influencing policymakers, this study explores the role of Saudi Arabian newspapers, Arab News and Saudi Gazette, in representing women's empowerment in the Kingdom of Saudi Arabia- the area which has been largely neglected by the contemporary research studies.

This study investigates how the Saudi press represented the issue of women's empowerment as stipulated in the vision 2030. The data (corpus) consist of newspaper articles, reports, stories, and editorials published by the English daily newspapers, namely, Arab News and Saudi Gazette. The study asks the following research questions. First, how does the Saudi press reproduce the women's empowerment discourse as stipulated in the Saudi Vision 2030? Second, how can corpus-based critical discourse analysis methods be used in the analysis of the ideological construction of women's empowerment in the Saudi press?

The rest of the paper is organized as follows. Part two surveys two main bodies of research. First, it gives a brief survey of media representation of human rights and newspaper discourse. Second, it surveys the previous studies on the Saudi Vision 2030. Part three defines the methodology and data 
collection methods. Part four is analysis and discussions. Part five is the conclusion.

\section{Media Representations of Human Rights}

There is a close relationship between media and human rights. This may be due to the idea that the media constitute a central source of information about global conditions including human rights issues. It is difficult to imagine how large publics know about the violations of human rights without the presence of the media. Balabanova (2014) argues that the media have been playing a crucial role in public freedoms, which represent the essence of human rights. Similarly, Papademas (2011) suggests that the media have an influential role in the political awareness of the public about human rights issues and forming public opinion, and reporting violations of human rights. The media, in every part of the world promote human rights such as the fight against racism, social security, workers' rights, food and shelter for all, the right to public assembly, freedom of expression, education, marriage and family, and freedom of thought. The media in particular express the voices of oppressed peoples struggling against all forms of oppressions (Ramanjaneyulu, 2015).

For the media to promote human rights, however, journalists and other media practitioners operating in their country or abroad must enjoy protection to ensure the best conditions for their profession (Tumber \& Waisbord, 2017). Some factors should be considered for the successful representation of human rights issues. Public access to information must be ensured through the diversity of sources and media prepared for it, allowing each individual to ascertain the facts and to form an objective opinion on events. To this end, journalists should have freedom of information and the greatest possible access to information. The media should also respond to the concerns of people and individuals, thus creating public participation in shaping the media (Farrell, Drywood, \& Hughes, 2019). This study explores how the media (newspapers) in Saudi Arabia represented women's empowerment, supposed a human rights issue, in the context of Vision 2030.

\section{Newspaper Discourse}

Discourse involves ideologies all over the place. Discourse is by nature ideological in several aspects; it encompasses beliefs and values about relations between people and groups and promotes social power and social goods (Gee, 
2012). Thus, discourse involves ideologies by demonstrating the way language runs ideology by acting as a vehicle (Tyson, 2006). Media are deeply involved in relations of power and ideology and their depictions of different matters have repercussions (Johnson \& Milani, 2010). Mass media discourses become interesting when, due to the reason that they exercise as well as involve hidden relations of power (Fairclough, 2013), Media portray events through certain patterns that include cognition, making selections, presenting and interpreting events, placing emphasis and exclusions. Through such patterns, discourse is usually organized (Gitlin, 2003). Print media are an influential mode of communication cum valuable source of information in transmitting events (Cissel, 2012). Newspapers use their institutional powers that may restrain the content of the news to endorse certain interpretations and de-emphasize others. Newspapers' expressions or the language used might be the words of the holders of power in a society (Fairclough, 2013). The news refers to meaning construction in a news article and its making can be explored in terms of beliefs, attitudes, and strategies involved in news production. It is claimed that news values reflect social, ideological, and economic values and conform to the ideological consensus of a society or culture (van Dijk, 1988).

The influential print media make readers depend on newspapers due to their coverage of issues, conflicts, and controversies. The press becomes more effective if its contents serve readers' interests (van Dijk, 1995b). According to Fowler (1991), newspapers' language is meant to construct ideologies, ideas, believes and their representations shape the narrative of a particular event. To sum up, newspapers are a source of our socio-political awareness and how we sense the world by reading newspaper reports daily (Fowler, 1991; van Dijk, 1991). Newspapers use language to construct values, beliefs, propositions, theories, ideas, and ideologies. Newspapers articles written by certain journalists promote official ideology and in a style that sounds authoritative and formal. Their discourse produced in a unique style commutatively facilitates a particular setting (Fowler, 1991) and has a targeted readership particularly if a newspaper holds an identifiable political or social stance (Douglas, 2009). Newspapers contribute to a variety of language employed in the media due to their unique linguistic content (Jucker, 1992). Given the arguments, the study investigates how the two fowling leading English dailies in Saudi Arabia represented women empowerment in the county about reforms promulgated in Vision 2030. 


\section{RESEARCH METHODS}

This study adopts corpus-based critical discourse analysis to explore the representation of women's rights in the Saudi press after the emergence of the Saudi Vision in 2016. Corpus-based critical discourse analysis is based on some tools including frequency, dispersion, concordance, and collocates that are used to make generalizations about the data. In discourse studies, corpus-based critical discourse analysis has many advantages including the use of big data, reducing researcher bias in terms of data selection, objectivity, reliability, replicability, and triangulation (Baker, 2006, p. 12): "By using a corpus, we at least can place several restrictions on our cognitive biases. It becomes less easy to be selective about a single newspaper article when we are looking at hundreds of articles-hopefully, overall patterns and trends should show through".

Given the nature of the data and the purposes of this study, it can be claimed that corpus-based approaches can be usefully used in conducting a critical discourse analysis quantitatively and qualitatively through a concordance, frequency, collocates, and dispersion.

The descriptive findings are generated by searching for particular discourse features in a corpus-typically a collection of texts of a specific register, but possibly a single extended text, such as a textbook or a novelusing computational means. Explaining the frequency, significance, and "use of these features generally involves reference to context, either the immediate cotextual environment or to other texts or other corpora of texts" (Thornbury, 2010, p. 271).

For this study, a corpus of 1578 news articles and editorials from 2 Saudi newspapers released in English was built. Data were collected from the online archive of the two newspapers (Arab News and the Saudi Gazette) within 20172020. All the selected data were written and released after the emergence of the Saudi Vision 2030 in 2016.

As a next step, Key Word in Context (KWIC) analysis was adopted in order to identify the lexical patterns in the corpus. The rationale is that these lexical patterns can be usefully used as predictors of the focus of texts. In order to do this, Conc software was used. Conc is a program developed by SIL language technology for generating keyword-in-context concordances of words within 
texts. One advantage with Conc is that it permits users to limit the concordance to just those words that match a specified pattern.

The two key words 'women' and 'Saudi Vision' were defined and their frequencies were calculated. A collocation analysis is then carried out in order to identify the themes that collocate most frequently with these two key words. Finally, a qualitative analysis is developed to provide an in-depth investigation of the linguistic phenomena and patterns generated through the KWIC and collocation analyses.

\section{Arab News}

Arab News has founded in 1975 by Hisham and Mohammed Ali Hafiz. It was the first newspaper that provided Saudi perspective in English on a wide range of global, regional, and national forums. The daily is one of 29 publications sponsored by Saudi Research \& Publishing Company (SRPC). Arab News is highly regarded by many sections of Saudi society that included nationals and foreign residents with a diverse group of readers and large distribution. It is representative of Saudi Arabia's policies and developments in society. (https://www.arabnews.com/node/51199/about-us).

\section{Saudi Gazette}

The second English language newspaper selected in this study is the Saudi Gazette that was established in 1978. Saudi Gazette is published by Okaz Organization for Press and Publication. The newspaper caters to varied sections of Saudi society; it disseminates diverse points of view and focuses on the news content which of interest to both national and residents. The daily has emerged as the "true window" of Saudi news to the world and beyond Saudi Arabia (https://saudigazette.com.sa/about-us).

\section{RESULTS \& DISCUSSION}

The recent years have witnessed unprecedented social and political changes in the Kingdom of Saudi Arabia. Different economic, social, and political reforms were enforced in light of the emergence of the Saudi Vision 2030. These reforms had positive implications for women's rights in the Kingdom. The Vision stressed the importance of gender equality and women's empowerment as indicated in the following extracts (https://hrc.gov.sa/en-us/Pages/vision2030.aspx): 
- $\quad$ Together we will continue building a better country, fulfilling our dream of prosperity and unlocking the talent, potential, and dedication of our young men and women.

- $\quad$ Our economy will provide opportunities for everyone - men and women, young and old - so they may contribute to the best of their abilities.

- $\quad$ Saudi women are yet another great asset. With over 50 percent of our university graduates being female, we will continue to develop their talents, invest in their productive capabilities and enable them to strengthen their future and contribute to the development of our society and economy.

- We aspire to have businesses that contribute to developing our society and our country, not be geared solely towards generating profits. We expect our companies to observe their social responsibilities and contribute to creating a sustainable economy, including by creating stimulating opportunities for young men and women that can help them build their professional careers. We will encourage the businesses that follow through on this commitment to participate in our country and to address national challenges.

In frequency and dispersion terms, 'women' is one of the most frequent terms identified in the corpora that represented the Vision 2030. This indicates that it is highly stressed in the Vision. It also reflects the Saudi interests in women's rights. Women's issues are central in almost all the themes of the Vision including the social, economic, and political vision of the Kingdom. The word 'women' collocates with building, contribution, development, productive capabilities, prosperity, and sustainable development. For this study, the two key terms 'women' and 'Saudi Vision' in the corpus were calculated using concordance analysis. This is shown below in Figure 1.

Here are some examples:

- $\quad$ Endorsing Vision 2030, youth and women are key. (Saudi Gazette, August 17, 2017)

- $\quad$ The ministry is planning to increase the participation of Saudi women in the labor market in line with the objectives of the Kingdom's Vision 2030. (Saudi Gazette, September 19, 2017) 
- Empowerment of women key to Saudi Arabia's progress (Arab News, October 9, 2018)

- Within the Saudi Vision 2030, Saudi Arabia on a fast track to gender equality. (Arab News, December 30, 2018)

- Undoubtedly, 2018 has been a landmark year for Saudi Arabia - but even more so for women in the Kingdom, who have had a momentous 12 months enjoying newly acquired freedoms and being at the forefront of change under reforms led by Crown Prince Mohammed bin Salman. (Arab News, December 30, 2018)

- $\quad$ Over the last four years, there has been a diverse shift in the demographic mix of Saudi Arabia's labor market, with the increasing number of women entering the workforce at the forefront of this change. With Vision 2030 now in its implementation phase, the government is carrying out its commitment to empowering women, recognizing their potential as active contributors to the economic development and modernization of the country. This falls in line with the target of increasing the employment rate among women from $22 \%$ to $30 \%$ by 2030 - Saudi Vision 2030. (Saudi Gazette, March 16, 2019)

- $\quad$ Female empowerment vital for Kingdom's Vision 2030 reforms, says Saudi Human Rights Commission GM. (Arab News, October 11, 2019)

- $\quad$ Giant gains for women under Vision 2030 (Arab News, June 21, 2020)

- Alobaidy praised the work of the Saudi leadership in support of the empowerment of women, and their social, economic, and developmental efforts, which form a significant aspect of Saudi Vision 2030. (Arab News, October 7, 2020)

- Women's participation in the workforce and the wider Saudi economy and having more women in leadership positions is one of the key goals of the Kingdom's Vision 2030 reform strategy (Arab News, October 31, 2020)

- Empowerment of women top priority of Vision 2030, says Council of Saudi Chambers head. (Arab News, November 20, 2020)

- The strategy to empower industry and increase local talent aims to activate the role of women in industrial development by the Saudi Vision 2030 aimed at enhancing their role in the national economy. (Arab News, December 8, 2020) 
Figure 1

A Frequency Analysis of the Key Terms in the Corpus

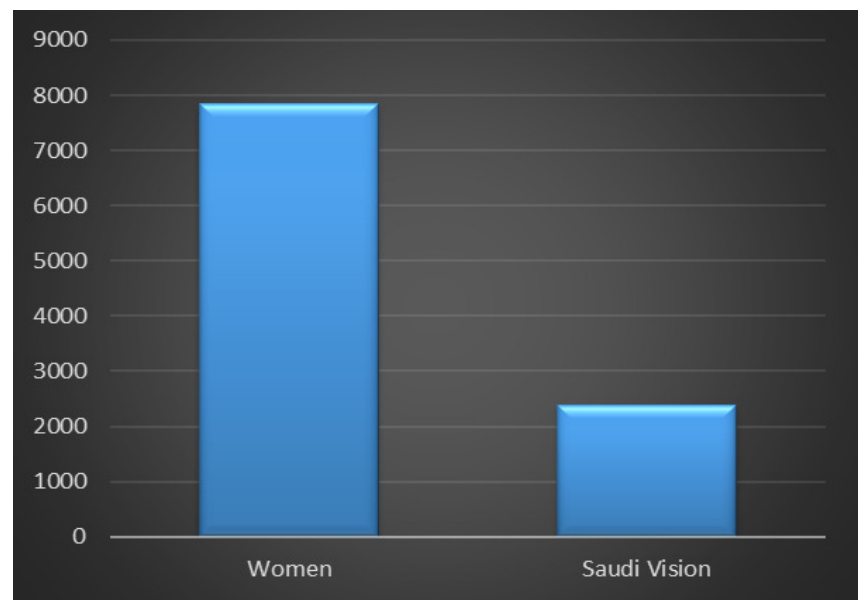

It is obvious that the discourse of women's empowerment stipulated in the Saudi Vision is reproduced in the Saudi Press as reflected in the two selected newspapers. The analysis of the corpora revealed that the Saudi press (Arab News and Saudi Gazette) played a dominant in reproducing women's empowerment stated in the Vision 2030. Media can reproduce dominant ideologies (Van Dijk, 1988). As noticed in the case of the Vision 2030 representations, it is evident that the Saudi press overwhelmingly participated in promoting the Vision with preferential treatment and a build a national consensus on the implantation of the vision. The print media have a long-lasting impact on readers by playing significant roles in transferring knowledge and information through several means including daily newspapers (Kress, 1990). The analysis of the Saudi press representation of the vision 2030 revealed that the newspapers necessitated/reproduced the importance of women's contribution to various sectors. The choice of several lexical items demonstrated that newspapers fully backed the endorsement of women's empowerment, for instance, objectives of the Kingdom's Vision 2030, women key to Saudi Arabia's progress, gender equality, at the forefront of change, female empowerment vital, giant gains, women in leadership positions, empowerment of women top priority and others. 
In quantitative terms, the two key terms 'women' and 'Saudi Vision' collocate with positive concepts of reforms, employment, participation, freedom, and development. A detailed collocation analysis is shown in Figure 2, collocates listed with their frequency.

Figure 2

A Collocation Analysis (Collocates \& Frequency)

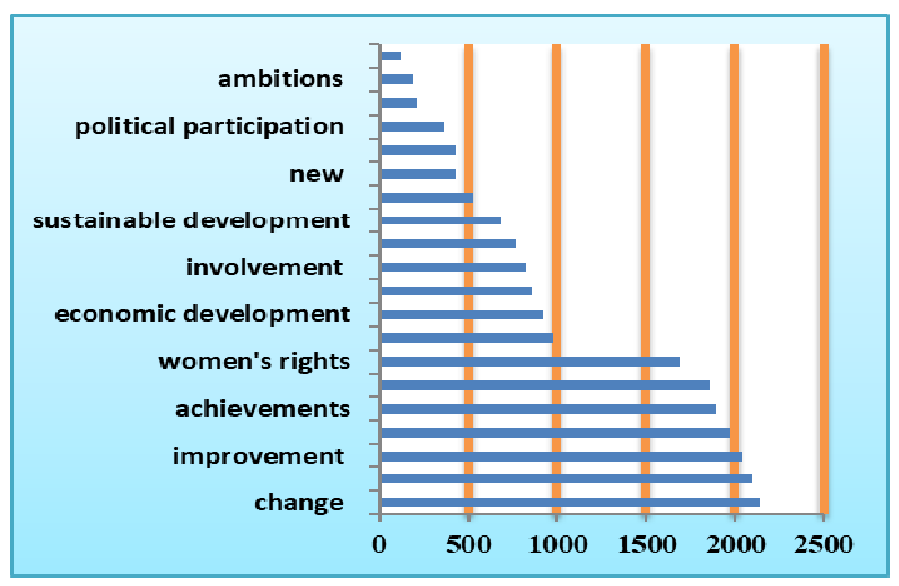

Newspapers play an instrumental role in taking matters of public interest and communicate with readers, arguably, with accuracy and in a balanced manner (Randall, 2007). As indicated in Figure 2, collocation analysis of the corpus also revealed that the newspapers positively reiterated the role of women in the Kingdom's uplift. For instance, the most common lexical collocations such as change, equal opportunities, improvement, participation, achievements, job opportunities, women's rights, implied that the two newspapers adopted a similar stance of promoting the vision 2030 goals. The two English dailies unanimously voiced their ideological beliefs, in favor of women's rights, to engage readers. Typically observing the media tradition of upholding national interests, both the newspaper circulated a common strategy of favoring all the articles of the vision 2030 that were meant to enhance women's empowerment. Newspapers serve readers' interests through comments, news reports, and opinions, promote a shared community consciousness, and construct a political or social position (Douglas, 2009). For 
instance, on one occasion the women's participation or inclusion in the national sectors was lexically described as gender progression. Hence, the newspapers, by reproducing the vision 2030 as a matter of national concern ideologically positioned the readers through several positive connotations. Thus, the two newspapers based on their ideological orientations with the country sent a positive message to the public. As noticed, the newspapers made an inclusive coverage of the vision 2030, shared their positions on all significant aspects of it, and defended all its promulgations. It is argued that whatever policy the newspapers adopt they have their unique tone of endorsing some aspects, for instance, the lexical giant gains for women used by the Arab News as noticed in this study.

It can be finally suggested that there is a correspondence between the Saudi Vision 2030 and the Saudi press discourse on women's empowerment in rejecting all forms of discrimination against women and highlighting the importance of gender equality as a requirement for sustainable development strategies. It is also apparent that the representation of women's empowerment in the Saudi press constitutes a distinct discourse genre in the sense that it is a directional, patterned, continuous, and purpose-oriented discourse that is deeply rooted in the Saudi social and cultural context. This discourse genre that can be referred to as the women's empowerment press discourse is based on a distinctive part of the Saudi culture and features the economic, social, and political developments in one of the most serious transitions periods in the history of the Kingdom of Saudi Arabia.

Unlike previous studies on vision 2030 (e.g., Alharbi, 2018; Altoaimy, 2018; Bah, 2018; Daghestani et al., 2018; Dahim, 2018; Mitchell \& Alfuraih, 2018), this study analyzed how women's empowerment was reproduced in the Saudi press as a matter of public and national concern, vis-à-vis vision 2030, which was largely neglected.

\section{CONCLUSION}

The study has analyzed how the two English language newspapers in the county, Arab News and Saudi Gazette, reproduced the Saudi Vision 2030 that aimed to change the public attitude towards women's rights and empowerment. The corpus contained newspaper articles, reports, stories, and 
editorials published in the selected newspapers. The newspapers inclusively covered the vision 2030, welcomed all its promulgations, and shared their positions on all transformational aspects of the vision. The newspapers based on their ideological affiliation circulated a positive message to the public and emphasized women's rights and gains stipulated in the vision. The Saudi Vision's representation of women's empowerment is endorsed in many ways in newspapers' articles, reports, stories, and editorials. It can be concluded that the Saudi press has been influential in producing and reproducing the women's empowerment discourse in Saudi Arabia in the light of the vision 2030. To its limitations, this study relied on the newspaper articles published after the emergence of the Saudi Vision in 2016. It is recommended that future research may be conducted by including the public views about the vision 2030 and women's empowerment in the country. Summary of the main topics covered or a re-statement of your research problem, but a synthesis of key points and, if applicable, where you recommend new areas for future research.

\section{Acknowledgments}

The researchers would like to gratefully thank the Deanship of Scientific Research (Prince Sattam Bin Abdulaziz University) for the support in finishing this research.[rgt]

\section{REFERENCES}

Alharbi, M. F. (2018). An analysis of the Saudi health-care system's readiness to change in the context of the Saudi National Health-care Plan in vision 2030. International Journal of Health Sciences, 12(3), 83-84.

Alomair, M. (2018). Collegiate Women in Saudi Arabia: Leading Collectively for the Development of Self, Others, and Society.

Alsaaidi, H. Z. (2020). Nation Branding and The Case of Saudi Vision 2030 and The Use of Twitter.

Alsuraihi, H. (2019). The Impact of Social Media on Women's Civic Engagement in Saudi Arabia: An Empirical and Critical Study of Saudi Women Councillors. University of York. 
Altoaimy, L. (2018). Driving change on Twitter: A corpus-assisted discourse analysis of the Twitter debates on the Saudi ban on women driving. Social Sciences, 7(5), 81-90.

Badran, A., Baydoun, E., \& Hillman, J. R. (2019). Major Challenges Facing Higher Education in the Arab World: Quality Assurance and Relevance: Springer International Publishing.

Bah, S. (2018). How feasible is the life expectancy target in the Saudi Arabian vision for 2030? Eastern Mediterranean Health Journal, 24(4), 401-404.

Baker, P. (2006). Using Corpora in Discourse Analysis. London: Continuum.

Balabanova, E. (2014). The Media and Human Rights: The Cosmopolitan Promise. London; New York: Routledge.

Burton, E. (2016). Business and Entrepreneurship in Saudi Arabia: Opportunities for Partnering and Investing in Emerging Businesses: Wiley.

Cissel, M. (2012). Media Framing: A comparative content analysis on mainstream and alternative news coverage of Occupy Wall Street. . The Elon Journal of Undergraduate Research in Communications, 3(1), 67-77.

Daghestani, D., Almunajem, G., Alabdulkarim, N., Alnuaim, R., \& Bassamah, A. (2018). Analysis of Saudi stock performance before and after the Saudi Vision of 2030. . European Journal of Accounting, Auditing and Finance Research, 6(2), 43-50.

Dahim, M. A. (2018). Impact of vision 2030 on traffic safety in Saudi Arabia. International Journal of Pediatrics and Adolescent Medicine, 5(3), 103-109.

Douglas, F. (2009). Scottish Newspapers, Language and Identity. Edinburgh, Scotland: Edinburgh University Press.

Duke, D. F. (2004). Central Eurasian States: Academic International Press.

Fairclough, N. (2013). Language and power (3rd ed.). London, England: Routledge.

Farrell, M., Drywood, E., \& Hughes, E. (2019). Human Rights in the Media: Fear and Fetish. London; New York: Routledge.

Forsythe, D. P. (2006). Human Rights and Comparative Foreign Policy: Manas Publications.

Fowler, R. (1991). Language in News: Discourse and ideology in the Press. London: Routledge. 
Gee, J. P. (2012). Social linguistics and literacies: Ideology in discourses (4th ed). New York, NY: Routledge.

Gitlin, T. (2003). The whole world is watching: Mass media in the making and unmaking of the new left (2nd ed.). Berkeley, CA: University of California Press.

Hodge, R., \& Kress, G. (1979). Language as ideology. London, England: Routledge and Kegan Paul Ltd.

Ienca, M., \& Andorno, R. (2017). Towards new human rights in the age of neuroscience and neurotechnology. Life sciences, society and policy, 13(1), 127.

Johnson, S., \& Milani, T. M. (Eds.). (2010). Language ideology and media discourse: Texts, practices, politics. New York, NY: Continuum International Publishing Group.

Jucker, A. H. (1992). Social stylistics: Syntactic variation in British newspapers. Berlin, Germany: Walter de Gruyter.

Koch, C., \& Tabatabai, A. (2020). The Quest to Launch Regional Integration Processes in West Asia and the Arabian Peninsula.

Kress, G. (1990). Critical discourse analysis. Annual Review of Applied Linguistics, 11,84-99.

Makhlouf, A. M. E. S. (2021). Saudi Schools' Openness to Change in Light of the 2030 Vision. American Journal of Educational Research, 9(1), 52-60.

Mitchell, B., \& Alfuraih, A. (2018). The Kingdom of Saudi Arabia: Achieving the Aspirations of the National Transformation Program 2020 and Saudi Vision 2030 Through Education. Journal of Education and Development, 2(3), 3646.

Papademas, D. (2011). Human Rights and Media: Emerald Group Publishing Limited.

Randall, D. (2007). The universal journalist (4th ed.). London, England: Pluto Press

Ramanjaneyulu, J. (2015). Role of the Media in Protecting Human Rights in India - a Socio Legal Dimension: CreateSpace Independent Publishing Platform.

Susi, M., Viljanen, J., Jónsson, E., \& Kučs, A. (2018). Human Rights Law and Regulating Freedom of Expression in New Media: Lessons from Nordic Approaches. London; New York: Routledge. 
Thornbury, S. (2010). What can a corpus tell us about discourse? In A. O'Keeffe \& M. McCarthy (Eds.), The Routledge Handbook of Corpus Linguistics (pp. 270287). London; New York: Routledge.

Tumber, H., \& Waisbord, S. (2017). The Routledge Companion to Media and Human Rights. London; New York: Routledge.

Tyson, L. (2006). Critical theory today: A user-friendly guide (2nd ed.). New York, NY: Routledge.

van Dijk, T. A. (1988). News as Discourse: L. Erlbaum Associates.

van Dijk, T. A. (1991). The interdisciplinary study of news as discourse. In K. B. Jensen \& N.W. Jankowski (Eds.), A handbook of qualitative methodologies for mass communication research (pp. 108-120). New York, NY: Routledge.

van Dijk, T. A. (1993). Principles of critical discourse analysis. Discourse \& Society, 4(2), 249-283.doi: 10.1177/0957926593004 002006

van Dijk, T. A. (1995a). Aims of critical discourse analysis. Japanese Discourse,1(1), 17-28.

van Dijk, T. A. (1995b). Discourse analysis as ideology analysis. In C. Schäffner \& A. Wenden (Eds.), Language and peace (pp. 17-33). Aldershot, England: Dartmouth Publishing.

van Dijk, T. A. (2006). Discourse and manipulation. Discourse \& Society, 17(3), 359-383. doi:10.1177/0957926506060250

Wodak, R. (2001). What CDA is about-a summary of its history, important concepts and its developments. In R. Wodak \& M. Meyer (Eds.), Methods of critical discourse analysis (pp. 1-13). London, England: SAGE Publications. 
The page has been intentionally left blank. 